\title{
The Impact of Halal Label and Social Support on Purchasing Behavior of Imported Instant Noodles
}

\author{
Anton Priyo Nugroho \\ Master of Islamic Studies \\ Islamic University of Indonesia \\ Yogyakarta, Indonesia \\ anton.priyo@uii.ac.id \\ Fajar Fandi Atmaja \\ Department of Islamic Economics \\ Islamic University of Indonesia \\ Yogyakarta, Indonesia
}

\author{
Ilham Itsnanisa Ghilma \\ Department of Islamic Economics \\ Islamic University of Indonesia \\ Yogyakarta, Indonesia
}

Yuli Andriansyah

Department of Islamic Economics

Islamic University of Indonesia

Yogyakarta, Indonesia

\author{
Siti Achiria \\ Department of Islamic Economics \\ Islamic University of Indonesia \\ Yogyakarta, Indonesia
}

\begin{abstract}
This paper analized impact of halal label and social support on purchasing behavior of imported instant noodles among Indomaret customers. This research used primary data by giving questionnaires to Indomaret customers with 75 respondents. The sampling used a purposive sampling technique. The data analyzed by multiple regression. The results showed that the halal label as a dummy variable did not affect the purchasing behavior of imported instant noodles. While social support has a significant effect on the purchasing behavior of imported instant noodles. Simultaneously, halal labels and social support influence the buying behavior of imported instant noodles.
\end{abstract}

Keywords: Imported Instant Noodles; Halal Labels; Social Support; Purchasing Behavior

\section{INTRODUCTION}

Currently, Indonesia has been implementing AEC (ASEAN Economic Community) or commonly referred to as regional, international and global free trade [1]. The existence of AEC can facilitate imported products into the domestic market with various types of attractive packaging. These imported products are sold freely in the market and consumers can easily get them. The existence of tight competition in Indonesia has resulted in a lot of interest from abroad to enliven the instant noodle industry. Several countries have exported their products to Indonesia such as South Korea, China, Thailand, Singapore, Japan, United Arab Emirates and Taiwan. However, there are several brands of instant noodles originating from the circulation, because they are proven to contain pig DNA including Samyang U-Dong, Samyang Kimchi, Nongshim feeling Shin Ramyun Black, and Ottogi feeling Yeul Ramen [2-3].

People must be careful in choosing the product, maybe there is something that is not known behind food products that are not suitable to be consumpted by Muslims. Errors in choosing food products can result in physical and spiritual losses for Muslims. Therefore, Muslim community must find information about the product to be consumed, halal labeling is one of the way. The large number of Muslim population in Indonesia certainly has a big influence on the developing culture in Indonesia, especially in terms of food consumption. In Islam, every Muslim is recommended to consume halal food.
Islamic teachings prohibit consuming illicit foods such as carcasses, blood, pork, slaughter without mentioning the name of Allah, animals that have been ravaged by wild animals, fanged beasts and alcohol. Knowledge about halal food is very important for Muslims and this greatly influences consumer behavior in purchasing. Muslim consumers are more likely to buy food that has been tested for halal or labeled as halal. The presence of halal labels provides a sense of security for consuming food. A study [4] showed that one of the factors that influenced consumers to buy was because of the halal label on the packaging. Furthermore, other research [5] showed that the presence of halal labeling will affect Muslim consumers interested and interested in consuming and buying a food product. Another research [6] showed that the inclusion of halal labels gave influence of $31 \%$ on asking for purchase. This means there are still other factors that influence buying interest.

Social support is a fator that can also influence consumer purchasing behavior. According to consumer purchasing behavior which influenced by cultural factors, social factors, personal factors, and psychological factors. Data buying behavior is influenced by friends and family, meaning that they decide to buy something of the product at the consideration of the family and friends who have bought the product. Family is the unit of consumption and the most important decision maker. According to a research [7], social support increases consumer confidence in making purchases.

\section{LITERATURE REVIEW}

Nugraha, et al. [8] examined the relationship between halal labeling and buying intention. The analytical method used is simple linear regression. This study shows that the increase in halal labels has a positive effect on Muslim consumers' interest in buying noodles and also vice versa if there is a decrease in halal labels which will reduce buying interest. Syahputra and Hamaroan [4] examined the relationship between halal labeling and purchasing decisions. The findings of this study indicate that the establishment of a halal label in the packaging of food products is one of the factors that influence consumers to buy.

Sukmaningtyas and Hartoyo [9] showed that value and lifestyle significantly affected the purchase of imported fruits. Sari and Sudardjat [5] examined the relationship between 
halal labeling and purchasing decisions on 82 respondents. The findings of this study indicate that halal labeling affects the purchasing decisions of imported food products in packaging. The existence of halal labeling provides safety and comfort for consumers.

Agustian $\mathrm{H}$ and Sujana [10] showed that halal labeling had a contribution of $49.7 \%$ in creating purchasing decisions, and the rest was influenced by other factors. Rambe and Afifuddin [6] showed that the halal label had an effect of $31.1 \%$ on the interest in buying instant noodles among students. Thus there are still other factors that influence student buying interest. Natadjaja, et al. [11] show that the relationship between visual merchandise variables to purchasing behavior variables is linear. The results of linear regression analysis showed that the visual merchandise variable had an effect of $53.7 \%$ on the overall behavior behavior of HappyMeal package purchases.

Kusumawati and Herlena [12] show that there is a positive relationship between the perception of the reference group and the decision to buy cosmetic products without the halal label. This means that the more positive perceptions of the reference group, the higher the decision to buy cosmetic products without a halal label on students.

\section{RESEARCH METHOD}

This research used descriptive method with stages in the form of data collection, then processing/analysing data and discussing it to find conclusions. The research was conducted at an Indomaret outlet in Yogyakarta on March 5 - March 19 2018. This sample data collection technique used purposive sampling based on characteristics: Muslims, those who bought imported instant noodles, and Indomaret customers. The study sample used as many as 75 people from Indomart customers, as many as 46 female and 29 male sex. Based on age distribution, 2 respondents included 15-20 years of age, 59 aged 21-25 years, 12 people aged $26-30$ years and 2 others having an age of more than 30 years.

\section{RESEARCH RESULT}

Descriptive analysis shows that $13.4 \%$ or 10 respondents stated that they had a high level of social support for imported instant noodles, $70.6 \%$ or as many as 53 respondents stated that they had a moderate level of social support for imported instant noodles, $16 \%$ or as many as 12 respondents stated that they had a low level of social support for imported instant noodles. In addition, as many as $8 \%$ or 6 respondents stated that they had a high level of buying behavior towards imported instant noodles, $57.3 \%$ or 43 respondents stated that they had moderate levels of buying behavior towards imported instant noodles, $34.7 \%$ or 26 respondents stated that they have a low buying behavior towards imported instant noodles.

The normality test produces an asymp.ig value of 0.635 , where the asymp.ig value is greater than 0.05 , which is $0.635>0.05$. So it can be concluded that the data is normally distributed. Multicoleration test showed tolerance value $(0.979>0.1)$ and VIF value $(1.022<10)$, thus the variable in the study did not occur multicoleration. Heteroscedasticity test shows that there is no heteroscedasticity because the significance value is $>0.05$, where the halal label significance value is $0.076>0.05$ and the significance value of social support is $0.710>0.05$.
Multiple linear regression aims to show the relationship between halal label variables (X1) and social support variables (X2) with the purchasing behavior variable of imported instant noodles (Y) create:

$$
\mathrm{Y}_{\mathrm{o}}=22,476+2,603 \mathrm{X} 1+0,375 \mathrm{X} 2+\mathrm{e}
$$

The regression test equation shows a constant (Constant) value of 22,476. That is, if all the independent variables (X), namely the halal label (X1) and social support (X2) are considered to be unchanged or constant, the size of the dependent variable (Y), namely the buying behavior of imported instant noodles has increased by 22,476 .

Partial test for $\mathrm{X} 1$ variable produces a significance value of 0.354 , because the significance of $0.354>0.05$, then Ho is accepted, meaning that variable $\mathrm{X} 1$ does not affect the dependent variable (Y). Whereas in the social support variable $(\mathrm{X} 2)$ the $\mathrm{t}$-value of $2.723>\mathrm{t}$-table value is 1.666 and significance (sig.) $0.008<0.05(5 \%)$. Thus it can be concluded that Ho is rejected and $\mathrm{H}_{2}$ is accepted. This means that the social support variable (X2) partially has a significant influence on the purchase behavior of imported instant noodles $(\mathrm{Y})$

Simultaneous tests to determine the effect of halal label (X1) and social support (X2) simultaneously on purchasing behavior (Y) produce $\mathrm{F}$ count, which is 3.854 and with a significant value of 0.026 obtained based on calculation of the significance level of 0.05 and df1 = k-1 ( 3-1 = 2), df $2=$ nk $(3-75=72)$, then the size of $F$ table is 2.74 . So that it can be concluded that $\mathrm{F}$ count is greater than $\mathrm{F}$ table which is $3.854>2.74$. So Ho is rejected, so it can be concluded that the halal label variable and social support together (simultaneous) affect the purchasing behavior variable.

The determination coefficient test ( $\mathrm{R}$ Square) produces $\mathrm{R}$ square of 0.097 so that, it can be concluded that all variables namely halal label and social support only affect $9.7 \%$ of the buying behavior of imported instant noodles, while (100\% $9.7 \%)=90,3 \%$ is influenced by other variables not examined in this study.

\section{DISCUSSION}

The results showed that there was a significant effect of social support on the buying behavior of imported instant noodles. This can be indicated by the value of $t$ count of 2.618 with a significance value of 0.011 . Because regression coefficients have a positive value and a significance value of $<0.05$, it can be concluded, social support has a positive effect on the behavior of buying imported instant noodles. From the results, it can be seen that the factor dominating in social support is friends. The number of families is 265 , parents are 405 , friends are 552, and organizations / groups are 367. This condition shows that the better the social support, the decision to buy imported instant noodles is higher. So this social support variable is in accordance with the theory of purchasing behavior [13] which is influenced by four factors, namely cultural, social, and personal factors.

Social support is a collection of several people who together consider closely similarities in the status or appreciation of a community that is constantly socializing among themselves both formally and informally [14]. Social factors are a collection of people who can influence individual behavior in carrying out actions based on habits [15]. Family members 
including can also have a strong influence on buying behavior. There are two kinds of families in the life of the buyer, namely the family as a source of orientation consisting of parents and family as a source of offspring, namely husband and wife and their children. The position of someone in each group can be explained in terms of roles and status. Each role will influence someone's buying behavior [16]. The results of other study [15] show that social factor significantly influence the purchasing behavior. The results of this study support previous research on social factors that significantly influence user interest in buying airplane tickets online [17]. The purpose of this social support itself is that there is a role for other people in making decisions for the purchase of a product. In this variable there are 3 indicators, namely family, friends and groups, they are the ones who take part in decision making in purchasing. In Islam it is also explained in the Quran that it is advisable to consult or seek the opinions of others when making a decision.

Based on the partial test results for the halal label variable produces a significant value of 0.979 with a probability of 0.05 . If the value is sig. $0.979>0.05$ means that there is no significant effect on the variable of purchasing behavior of imported instant noodles. Halal labels in this buying behavior are not mutually influential because consumers are not too attentive and not interested in halal labels when buying imported instant noodles. In this study of 75 respondents, 17 people did not pay attention to halal labels and 58 paid attention to halal labels. Whereas according to (Suryani, 2012) in his research shows that halal labels is only known by a little of the people, so that the relationship of halal labels to purchasing decisions is very small. For this reason, the relevant parties need to provide information about halal products for consumption.

So the reason halal label has no influence towards the purchasing behavior, is because because of lack of knowledge and information about halal labels, consumers do not pay too much attention and care about halal labels on packaging, they will immediately take instant noodle products without regard to halal labels. In Islamic economics, all activities have motives and goals, namely the achievement of Falah. So in purchasing behavior it is recommended to pay attention to halalness. So it can be concluded that there are still many people who do not fully understand the halal label and override the objectives of Islamic Economic activities.

\section{CONCLUSION}

Based on the problem formulation, data analysis and discussion that has been carried out in the previous chapter, conclusions can be obtained as follows. Social support has a relationship and partially has a significant effect on the behavior of purchasing of imported instant noodles, indicated by a significant level of $0.008<0.05$. This shows that social support has a positive influence on the buying behavior of imported instant noodles. The halal label contained in imported instant noodles has no relationship and partially has no significant effect on the behavior of purchasing imported instant noodles, indicated by a significant level of $0.375>0.05$, indicating that there are still many consumers who do not care about halal labels when buy imported instant noodles.

\section{REFERENCES}

[1] Darmadji A and Andriansyah Y 2013 Curriculum of Islamic economics and finance in Islamic University of Indonesia: Challenges of ASEAN Economic Community Global Journal of Business and Social Science Review 1(1) 17-24

[2] Idris M 2017 Banyak mie instan impor masuk RI, dari mana asalnya? Detik.com Retrieved from https://finance.detik.com/berita-ekonomibisnis/d-3537217/banyak-mie-instan-impor-masuk-ri-dari-manaasalnya

[3] Idris M 2017 RI impor mie instan, paling banyak dari Korea dan China Detik.com Retrieved from https://finance.detik.com/berita-ekonomibisnis/d-3537073/ri-impor-mie-instan-paling-banyak-dari-korea-danchina

[4] Syahputra A and Hamoraon H D 2015 Pengaruh labelisasi halal terhadap keputusan masyarakat kecamatan perbaungan dalam pembelian produk makanan dalam kemasan Ekonomi dan Keuangan 2(8) 475-487

[5] Sari D K and Sudardjat I 2013 Analisis pengaruh labelisasi halal terhadap keputusan pembelian produk makanan impor dalam kemasan pada mahasiswa kedokteran Universitas Sumatera Utara Ekonomi dan Keuangan 1(4) 49-56

[6] Rambe Y M and Afifuddin S 2012 Pengaruh pencantuman label halal pada kemasan mie instan terhadap minat pembelian masyarakat Muslim (Studi kasus pada mahasiswa Universitas Al-Washliyah, Medan) Ekonomi dan Keuangan 1(1), 36-45.

[7] Puspawati D 2016 Pengaruh dukungan sosial dan interaktivittas terhadap keputusan konsumen melakukan pembelian melalui scommerce Prosiding Seminar Nasional dan The 3rd Call For Syariah Paper (SANCALL 2016) 525-535

[8] Nugraha R, Mawardi M K and Bafadhal A S 2017 Pengaruh labelisasi halal terhadap minat beli konsumen (Survei pada mahasiswa muslim konsumen mie samyang berlogo halal Korean Muslim Federation di Kota Malang) Administrasi Bisnis 50(5) 113-120

[9] Sukmaningtyas A and Hartoyo 2013 Pengaruh nilai dan gaya hidup terhadap preferensi dan perilaku pembelian buah-buahan impor Jurnal Ilmu Keluarga \& Konsumen 6(1) 39-48

[10] Agustian H E and Sujana 2013 Pengaruh labelisasi halal terhadap keputusan pembelian konsumen studi kasus pada produk Wall's Conello Jurnal Ilmiah Manajemen Kesatuan 1(2) 169-178

[11] Natadjaja L, Dewi F R and Setyawan D 2009 Studi pengaruh visual merchandise untuk anak terhadap perilaku pembelian paket HappyMeal di Restoran McDonald's Surabaya Desain Komunikasi Visual Nirmana 11(1) 41-59

[12] Kusumawati Y and Herlena B 1998 Hubungan antara persepsi terhadap kelompok referensi dengan pengambilan keputusan membeli produk kosmetika tanpa label halal pada mahasiswi Muslim Psikologi Integratif 2(1) 100-109

[13] Kotler P 2003 Manajemen Pemasaran (Jakarta: Indeks Kelompok Gramedia)

[14] Lamb H 2001 Pemasaran (Jakarta: PT Salemba Empat)

[15] Mayvita P A, Alfisah E and Hidayah R E 2016 Faktor-faktor yang mempengaruhi perilaku mahasiswa dalam memilih jurusan pada Fakultas Ekonomi UNISKA Al-Ulum: Jurnal Ilmu Sosial dan Humaniora 2(3) 199-210

[16] Anoraga P 2000 Manajemen Bisnis (Jakarta: PT Rineka Cipta)

[17] Susanti Y and Gunarsih T 2008 Pengaruh sikap terhadap perilaku, faktor sosial dan kontrol keperilakuan yang dirasakan terhadap minat pembelian tiket pesawat secara online Nasional Conference on Managemant Research Makassar, Indonesia. 